\title{
Corporate Taxation and the Choice of Patent Location within Multinational Firms
}

\author{
Tom Karkinsky \\ Nadine Riedel
}

CESIFO WORKING PAPER NO. 2879

CATEGORY 1: PUBliC FinANCE

DECEMBER 2009

\footnotetext{
An electronic version of the paper may be downloaded

- from the SSRN website:

- from the RePEc website:

www.SSRN.com

Www.RePEc.org

- from the CESifo website:

www.CESifo-group.org/wp
} 


\title{
Corporate Taxation and the Choice of Patent Location within Multinational Firms
}

\begin{abstract}
Corporate patents are perceived to be the key profit-drivers in many multinational enterprises (MNEs). Moreover, as the transfer pricing process for royalty payments is often highly intransparent, they also constitute a major source of profit shifting opportunities between multinational entities. For both reasons, MNEs have an incentive to locate their patents at affiliates with a relatively small corporate tax rate. Our paper empirically tests for this relationship by exploiting a unique dataset which links information on patent applications to micro panel data for European MNEs. Our results suggest that the corporate tax rate (differential to other group members) indeed exerts a negative effect on the number of patents filed by a subsidiary. The effect is quantitatively large and robust against controlling for affiliate size. The findings prevail if we additionally account for royalty withholding taxes. Moreover, binding 'Controlled Foreign Company' rules tend to decrease the number of patent applications.
\end{abstract}

JEL Code: H25, F23, H26, C33.

Keywords: corporate taxation, multinational enterprise, profit shifting.

\author{
Tom Karkinsky \\ Oxford University CBT \\ Said Business School \\ Park End Street \\ UK - Oxford, OX1 1 HP \\ United Kingdom \\ tom.karkinsky@sbs.ox.ac.uk
}

\author{
Nadine Riedel \\ Oxford University CBT \\ Said Business School \\ Park End Street \\ UK - Oxford, OX1 1 HP \\ United Kingdom \\ nadine.riedel@sbs.ox.ac.uk
}

November 3, 2009

We are indebted to the Institute for Fiscal Studies (IFS), especially to Rachel Griffith and Helen Miller, for providing us access to the dataset used in this paper and for several helpful comments. Moreover, we thank Wiji Arulampalam, Steven Bond, Mihir Desai, Michael Devereux, Clemens Fuest, Rick Krever and participants of seminars at the University of Oxford for helpful comments and suggestions. 


\section{Introduction}

Anecdotal evidence suggests that multinational companies strategically locate ownership of their intellectual property at tax-havens, with the intention of minimizing their corporate tax burden. For example, the Wall Street Journal reports that Microsoft, a company which earns three-fourths of its revenue from license fees, is "increasingly setting up units in Ireland that route intellectual property and its financial fruits to the low-tax haven" (Wall Street Journal, 2005). In the UK, the Guardian writes that "three FTSE 100 companies have quietly transferred their valuable intellectual property to low-tax locations", meaning that "they can reduce their UK-based profits and hence their British tax bills" (The Guardian, 2009).

The rationale behind locating intellectual property at low-tax affiliates is two-fold. First, intangible assets are increasingly perceived to be important value-drivers within multinational enterprises (MNEs) (e.g. see Hall, 2001, Zingales, 2000). Locating them at low-tax affiliates is thus an attractive tax saving strategy as it implies that the intangibles' profits become taxable at a low corporate tax rate. Second, the common good nature of intellectual property involves that it is used as an input factor by several operating affiliates within the multinational group which then pay a royalty or license fee to the intangibles-owner (see e.g. Markusen, 1995). As arm's length-prices for these firm-specific royalty payments are commonly not available to tax authorities, MNEs can distort royalty prices in order to shift profit between the operating entities and the intangibles-owner. Consequently, it pays for the MNE to locate its intellectual property at a low-tax country as this establishes a profit shifting link between all operating affiliates and a tax-haven subsidiary (see also Dischinger and Riedel, 2008). ${ }^{1}$

Tax authorities have raised increasing concerns about the relocation of intangible assets to low-tax economies as they fear that the mitigation of intellectual property deteriorates their country's corporate tax base (see e.g. Hejazi, 2006). Nevertheless, studies which go beyond anecdotal evidence and investigate the link between corporate taxation and the location of intellectual property in a systematic empirical framework are scarce as information on intellectual property ownership is commonly not available in standard firm data sets.

In the following, we will investigate this relationship by exploiting a new and unique

\footnotetext{
${ }^{1}$ In the contrary, if the intangible asset is located at a high-tax subsidiary, the MNE obtains shifting possibilities solely between the tax haven and the intangibles-holding firm whereas other high-tax affiliates remain without shifting link to a low-tax country.
} 
data source that connects accounting and ownership information for a large panel of European multinational subsidiaries to data on patent applications provided by the European Patent Office (EPO). Thus, our analysis focuses on the location of corporate patents as a particular form of intangible property. The data is available for the years 1995 to 2003. To identify the impact of corporate taxes on multinational patent location, we additionally merge information on various aspects of the corporate taxation system. Following our argumentation above, we account for the host country's corporate tax burden (as measured by the statutory corporate tax rate) and the relative attractiveness of a subsidiary's corporate taxation scheme compared to other firms in the multinational group (as measured by the corporate tax rate differential between the entities). Moreover, our analysis takes into account that the effective tax burden on royalty income may be affected by withholding taxes on royalty payments and so-called Controlled Foreign Company (CFC) rules which are implemented at the subsidiary's parent location and attempt to refrain MNEs from avoiding taxes in their residence country by making passive (patent) income earned at low-tax subsidiaries taxable at the parent location.

We assess the link between corporate taxation and the number of patent applications in various empirical specifications. Our most preferred model is a negative binomial framework which controls for affiliate fixed effects. The results suggest that both, the corporate tax rate and the tax rate differential to other group affiliates, exert a negative impact on the subsidiary's number of patent applications whereas the effects are robust against the inclusion of time-varying country characteristics and affiliate size controls. Quantitatively, the coefficient estimates are sizable, implying semi-elasticities of -2.3 and larger. Thus, the regressions indeed suggest that MNEs distort the location of patents in favor of affiliates with relatively low corporate tax rates. Moreover, we find that the negative effect of taxes on the number of patent applications prevails if we construct tax measures that additionally account for withholding taxes on royalty income. Last, our regressions indicate that CFC regulations are effective in refraining MNEs from locating patents at low-tax locations since binding CFC rules tend to reduce the number of patent applications filed by a corporate subsidiary.

Our study contributes to the literature on multinational income shifting. A growing number of papers has provided empirical evidence which suggests that MNEs transfer profits from high-tax to low-tax affiliates in order to diminish their corporate tax burden (see e.g. Devereux, 2007; Huizinga and Laeven, 2008). Recent work has connected these multinational profit shifting activities to the ownership of intellectual property. ${ }^{2}$ The

\footnotetext{
${ }^{2}$ Several studies suggest a strong general link between intangible property ownership and the emer-
} 
idea is that arm's length prices for intra-firm royalties charged for the use of firm-specific intangible assets are hardly observable to tax authorities and that multinationals can thus easily distort the associated transfer prices and shift profits to low-tax countries. This notion is confirmed by a set of empirical papers which show that profit shifting activities are larger in MNEs with high intellectual property holdings and high R\&D intensities (see e.g. Grubert, 2003).

However, in contrast to our work, these papers neglect that corporate taxation may distort the location of intangible assets itself as MNEs have an incentive to ensure that their patent returns are taxable at a low rate and that profit shifting channels to lowtax countries are available to operating affiliates world wide. In this sense, our analysis is most closely related to two recent papers: Mutti and Grubert (2008) provide evidence that US MNEs structure their operation in such a way that royalty income accrues with foreign subsidiaries in low-tax countries. However, as they do not observe information on patent ownership or license agreements, their evidence is indirect. Dischinger and Riedel (2008) find that the corporate tax rate exerts a negative effect on the size of intangible property assets, as reported on company balance sheets. However, using balance sheet data has limitations as it does, for example, not allow for a disaggregation of the legal assets which constitute the reported intangible asset figure whereas our study focuses on a clearly identified form of intellectual property.

Moreover, our paper is related to a small literature that investigates how the tax system affects the location of R\&D activity within multinational companies. For the US, Hall (1993) and Hines (1994) study the responsiveness of corporate R\&D to the Research and Experimentation Tax Credit and find significant R\&D price elasticities. Similarly, Jaffe and Hines (2001) determine how US R\&D expense deduction rules affect the location of R\&D by US multinationals. ${ }^{3}$ Bloom et al. (2002) confirm a significantly positive effect of $R \& D$ tax credits on the level of $R \& D$ expenditures using macro data

gence of multinational firms as with intellectual property holdings the threat of knowledge dissipation tends to favor market entry through foreign direct investment over other entry modes like licensing agreements with third parties (see e.g. Ethier and Markusen, 1996; Saggi 1996, 1999; Fosfuri, 2000; Markusen, 2001; Gattai and Molteni, 2007).

${ }^{3}$ The study of Jaffe and Hines (2001) is also related to ours in the sense that they use a data set which is the US equivalent to our data as it equally combines firm information and data on patent applications. One important difference though is that Jaffe and Hines (2001) are interested in the location of $R \& D$ rather than in the location of the corporate patents. Thus, they exploit the patent office data with respect to the information on the location of the patent inventor while we in contrast use the information on the location of the patent applicant. Note that inventor and applicant location differ for a substantial fraction of the patents in our data set, being well above $10 \%$. 
for major OECD countries. However, all of the cited papers focus on the role of R\&D tax credits and abstract from potential effects of the corporate tax system on the location of the legally protected output to R\&D activities, i.e. the corporate patents. Our study fills this gap and assesses the impact of corporate taxation on the choice of patent location accounting for various tax incentives, including the statutory corporate tax rate, withholding taxes and CFC legislations.

The paper is organized as follows. Section 2 presents the theoretical considerations. Sections 3 and 4 describe the data set and the estimation methodology. In Section 5, we show the empirical results and Section 6 concludes.

\section{Theoretical Considerations}

This section explores how the international corporate tax system may affect patent ownership within multinational firms. The following discussion leads on to Section 3, where we construct the tax variables used in our empirical analysis.

The value of a patent stems from its provision of a temporary monopolistic right to exploit the associated technology within a given geographic area. Any party that wishes to use the technology in that geographic area will have to pay a royalty fee to the patent owner. To avoid knowledge dissipation, MNEs have a tendency to sell the right to exploit a patented technology to affiliated companies only (see Introduction) whereas the latter are forced, by the transfer price system, to pay a royalty to the patent owner. While in many cases the inventor of the technology is also the owner of the associated patent, our data suggests that the location of $R \& D$ activities and the resulting patents can also be geographically separated within multinational groups, as the locations are split in a non-negligible number of cases. ${ }^{4}$

The MNE's decision where within the group to locate its corporate patents is expected to be influenced by a set of tax considerations. First, patents belong to the value-drivers in multinational firms (see e.g. Hall, 2000, 2007; Hall et al., 2005) and as their income becomes part of the owner's corporate tax base, the MNE has an incen-

\footnotetext{
${ }^{4}$ According to practitioners a geographical separation of the $\mathrm{R} \& \mathrm{D}$ and patent location is easy to implement. First, tax authorities can hardly track the link between R\&D activities and patent location, especially if several multinational affiliates participated in the development of a patent. Second, R\&D and patent location can be split by officially assigning the project risk to a different affiliate than the one hosting the $R \& D$ activity. The risk-bearing unit in charge for the project then pays a fixed fee comprising the development costs and a fixed margin to the $\mathrm{R} \& \mathrm{D}$ department while it receives the resulting patents and the associated patent returns.
} 
tive to locate the patent in a country with a small corporation tax. This incentive is especially strong as patented knowledge (like other intellectual property) has a trade price of zero and the location of patents and output production can henceforth be geographically separated at low costs. ${ }^{5}$

Second, not only the host country's corporate tax burden may be decisive for the location of multinational patents but also the affiliate's relative attractiveness as a patent location, in comparison to other firms within the same multinational group. We thus construct a tax variable which calculates the tax rate difference between the considered affiliate and other firms within the MNE. This variable is also expected to capture profit shifting incentives since locating a patent in a country with a low-tax rate and then selling the right to use this patent from there to high-tax affiliates in the same group, opens up profit shifting opportunities between the high-tax locations and the patent-holding subsidiary in the low-tax economy. ${ }^{6}$

Third, if royalty income is paid across a national border, the country of the royalty paying party usually charges a royalty withholding tax on the income stream. To avoid international double taxation, royalty receiving countries apply a tax credit for the withholding taxes already paid before assessing the income stream at their corporate tax rate. Consequently, the effective tax burden on international royalty payments is determined by the size of the corporate income tax at the royalty-receiving country in relation to the size of the withholding tax imposed by the royalty-paying country. If the receiving country's corporate tax rate is higher than the withholding tax paid at source, a full credit will be provided for the tax already paid, meaning that the royalty income is effectively taxed at the statutory tax rate of the royalty-receiving economy. In this

\footnotetext{
${ }^{5}$ Note in this context that some countries have introduced special low tax rates on royalty income in their legislation. Since the introduction of these special rates are very recent, they fall outside of our sample period of 1995-2003, and we do not take them into consideration in our empirical analysis. Precisely, special low royalty income tax rates were recently introduced in Hungary, Luxembourg and the Netherlands. Ireland in turn has exempted royalty income from taxation since 1973. However, until 2008 this exemption was granted only if the MNE equally undertook the R\&D in Ireland. As patent relocation schemes often imply a geographical separation of $R \& D$ and patent ownership, we use the Irish standard corporate tax rate in our empirical analysis but in robustness checks reran the analysis using a zero income tax rate for Ireland which turns out to leave the qualitative and quantitative results unaffected.

${ }^{6}$ Note that locating the patent at one of the high-tax affiliates is less attractive as it implies that the MNE gains only one profit shifting link between the high-tax intangibles-owner and a low-tax country while other operating affiliates in high-tax economies remain without a shifting link (see also Dischinger and Riedel, 2008).
} 
scenario the withholding tax rate does not affect the corporate after-tax income and consequently the patent location decision. However, if the royalty-receiving country's corporate tax rate falls short from the withholding tax paid at source, the tax rebate is restricted to the corporate income tax due. In this scenario, the royalty income is effectively taxed at the withholding rate which generates incentives for the MNE to locate patents in countries that have favorable bilateral tax treaties and thus ensure low withholding taxes on the royalty income stream.

Last, our analysis accounts for so-called 'Controlled Foreign Company' (CFC) rules which intend to prevent companies from avoiding taxes in their residence country by diverting income to subsidiaries in low tax jurisdictions. CFC rules operate by imposing an immediate tax charge at the level of the parent company on income earned in a foreign subsidiary if a set of criteria is fulfilled. The criteria vary across countries but in essence include an ownership threshold (e.g. the parent must hold more than $10 \%$ of the equity in the subsidiary), a tax threshold (e.g. the foreign tax paid on the subsidiary income must be less than $60 \%$ of the tax that would have been paid had the income been generated at the parent's location), and a threshold which specifies that a certain proportion of the subsidiary's income must arise from 'passive' or 'tainted' sources (e.g. a fraction greater than 5\%). In most national CFC laws, royalties are considered to be passive income. If the $\mathrm{CFC}$ criteria for a given subsidiary are satisfied, the passive income of that subsidiary effectively becomes taxed at the corporate rate at the parent location, even if the income is not repatriated. We thus hypothesize that subsidiaries that are subject to CFC rules are less likely to own patents.

Summarizing, this section suggests that MNEs have an incentive to locate their corporate patents at affiliates which observe a low corporate tax burden relative to other group members and do not face binding CFC legislations. From a practical point of view, MNEs can exploit different organizational structures to achieve a (re)location of patents to low-tax economies. First, they may obviously shift whole R\&D units to lowtax affiliates. As this, however, may involve considerable costs, practitionners claim that a more often applied structure is to engage in subcontracting agreements in which the R\&D head office is located in a low-tax country and subcontracts research to operating $R \& D$ units at other affiliates. The latter earn a fixed margin on their costs while the head office bears the project risk, receives the associated patent rights and earns all residual profits. Apart from subcontracting agreements, affiliates may moreover also engage in cost-sharing arrangements in which several affiliates share the costs and benefits of developing a (later patented) technology. If appropriately structured, these cost sharing agreements allow MNEs to assign an overproportional amount of profits to 
low-tax affiliates. In the following, we will empirically test whether and to what extent multinationals engage in these relocation activities. The next section will describe our dataset and the construction of the tax variables used in our empirical analysis.

\section{Data description}

Our analysis is based on a unique dataset which links patent applications to firm-level accounting and ownership data. The dataset has been generated by a match of patent applications from the European Patent Office (EPO) to the European firm data base AMADEUS, in a research effort undertaken by the Institute for Fiscal Studies (see Abramovsky et al. (2008) for details).

The patents data comes from the EPO's Worldwide Patent Statistical Database (PATSTAT) which contains information on all patent applications to the EPO dating back to 1978, including (among others) information on the name of the patent applicant and the application date. The data version used in this paper is October 2007 and comprises up to 100,000 patent applications per year. Firms seeking patent protection in a number of European states may file an application directly at the EPO and designate the relevant national offices (among those covered by the EPO) in which protection is sought. ${ }^{7}$ Filing a patent with the EPO firstly enables a firm to make a single application which is cheaper than filing separately in each national office and secondly allows it to delay the decision over which national states to further the application in. Thus, it is especially attractive to file the valuable patents with the EPO which a firm intends to exploit in several European markets.

The data on patent applications is merged to European company accounts information collected by Bureau van Dijk in the AMADEUS database. ${ }^{8}$ The company data is available in panel format for the years 1995 to 2003 and thus, we also restrict the merged data to the years 1995 to $2003 .{ }^{9}$ One advantage of the AMADEUS data is that

\footnotetext{
${ }^{7}$ The EPO is not a body of the European Union and as a result the states which form part of the European Patent Convention (the legal basis for the EPO) are distinct from those in the European Union. See: http://www.epo.org/about-us/epo/member-states.html. Note moreover that our data does not capture patent relocations after the application process. However, as outright sales of intangible assets are scarce in practice, we consider our analysis to capture the most important strategies to transfer patent ownership to low-tax economies (see e.g. OECD, 2009).

${ }^{8}$ Precisely, the IFS applies a standard name matching procedure to link the two data sets. For detailed information see Abramovsky et al. (2008).

${ }^{9}$ As the PATSTAT data on patent applications is available for a longer time span, we nevertheless
} 
it covers a large number of firms across many countries and includes both, accounting and ownership information. We capture subsidiaries that are ultimately owned by a parent firm whereas ultimate ownership implies that the parent is an independent company (i.e. no single firm owns more than $24.99 \%$ of the shares) and holds a recorded share of over $24.99 \%$ in the subsidiary (whereas the ownership shares are commonly considerably higher, being close to a $100 \%$ in the majority of cases). The parent is the highest firm in the ownership chain for which the above conditions hold. Note, however, that one drawback of the AMADEUS database is that it records ownership at a single point in time which is the year 2004 in our sample. In line with previous papers, we are however not too concerned about this issue as misclassifications of parent-subsidiary connections introduce noise into our analysis (where group information is exploited in the regressions) and tend to bias our results against zero. Thus, the associated coefficient estimates have to be interpreted as a lower bound to the true effect.

The matched data comprises patent applications filed by firms from 18 European countries: Belgium, Czech Republic, Denmark, Finland, France, Germany, Greece, Ireland, Italy, Luxembourg, Netherlands, Norway, Poland, Portugal, Spain, Sweden Switzerland, United Kingdom. The match rates for the data sets are satisfactory with a proportion of $50 \%$ to $70 \%$ of patent owning firms in PATSTAT being matched to AMADEUS in the large European countries. For some East-European countries match rates can be smaller, as low as $25 \%$, which is driven by a small coverage of AMADEUS in those countries and a low matching effort of the IFS (see Abramovsky et al. 2008). In terms of the number of patents matched per country, success rates are even higher ranging between $80 \%$ and $99 \%$ which reflects that large companies owning a lot of patents are well represented in AMADEUS.

Since our analysis centers around tax effects on the location of patents within MNEs, we restrict the dataset to subsidiaries belonging to multinational groups. For a multinational subsidiary to be included in the data, it had to apply for a patent at least once within our sample period and thus we restrict our analysis to firms which in general qualify as patent holding subsidiaries. As the coverage of multinational firms in AMADEUS is much better than the coverage of national firms, we are confident that our dataset includes all important patent holding subsidiaries in Europe.

From this data, we determine the annual number of patent applications filed by a corporate subsidiary and hence, the observational unit in our analysis is the multina-

reran our regressions without firm data controls for the whole time period covered in PATSTAT and found comparable results to the ones reported in this paper. 
tional affiliate per year. In total, our sample comprises 85, 330 observations for 11,828 multinational subsidiaries. Country statistics for our sample are presented in Table 1. The pattern of multinational subsidiaries and their parent countries broadly resembles the pattern of multinational firms in Europe with the largest fraction of firms in France, Germany and the United Kingdom. ${ }^{10}$ The very high number of UK subsidiaries partly reflects a high matching effort of the IFS for that country. Switzerland and Netherlands host a high number of patent owning subsidiaries, which may partly reflect the favorable tax treatment of royalty income in these countries. Note, moreover, that while our subsidiary sample is restricted to European countries, parent firms (i.e. global ultimate owners) may equally be located in a country outside the EU. As depicted in Table 1, most of the non-European parent firms reside in the US and Japan.

Moreover, basic descriptive statistics for the data are presented in Table 2. On average, a subsidiary applies for 0.7 patents per year whereas the patent count varies between a minimum of 0 patents and a maximum of 20 patents. ${ }^{11}$ Moreover, we construct a binary variable which takes on the value 1 if the subsidiary applies for a positive number of patents in a considered year and 0 otherwise; $28 \%$ of the subsidiary-year combinations exhibit a positive number of patent applications.

To determine the effect of corporate tax legislation on the multinational choice of patent location, we add information on the corporate tax systems of each country. First, we add the statutory tax rate applicable in a subsidiary's host country (obtained from EUROSTAT). Second, we capture the relative attractiveness of an affiliate as a patent location by calculating the tax measure $t d_{i t}$, which captures the tax rate difference between subsidiary $i$ 's statutory tax rate at time $t$ and the statutory tax rate of all other affiliates within the corporate group, including the parent firm. To do so, we have to restrict our analysis to subsidiaries for which AMADEUS contains information on the ownership structure of the whole multinational group. ${ }^{12}$ Formally, $t d_{i t}$ is defined as

$$
t d_{i t}=\sum_{j} \frac{1}{N}\left(t_{i t}-t_{j t}\right), \quad i \neq j
$$

\footnotetext{
${ }^{10}$ Note that Table 1 depicts the subsidiary and parent countries for the affiliates in our sample and thus, the sum of both columns adds up to the total number of subsidiaries in our sample.

${ }^{11}$ To avoid that our results are driven by outliers, we deleted a set of companies with very large patent application numbers from our analysis which is however not decisive for our qualitative results.

${ }^{12}$ Precisely, this implies that information on the subsidiary's ultimate owner must be available with AMADEUS as well as a full list of the affiliates owned by this ultimate owner. Note that, although AMADEUS does provide accounting information for affiliates within Europe only, the ownership information is available on a worldwide basis, i.e. includes subsidiaries outside European borders.
} 
whereas $j$ indicates all foreign affiliates in the same multinational group as subsidiary $i$ and $N$ depicts the overall number of foreign affiliates. Note, that equation (1) implies the calculation of an unweighted average which we consider to be appropriate in our context as size information (e.g. on the affiliates' total asset investment) is available only for a subset of multinational subsidiaries and we would thus loose a non-negligible number of subsidiaries when calculating a size-weighted average. However, in robustness checks we experimented with a size-weighted average tax difference measures and did not find our qualitative results to change. Moreover, in the calculation of $t d_{i}$ we account for foreign affiliates which are either the subsidiary's parent firm or owned by the group with $100 \%$ of the ownership rights only. The rationale behind this is that we consider partially owned subsidiaries to be less likely to hold corporate patents and also to be less likely to be integrated in the MNE's profit shifting activities (see e.g. Weichenrieder, 2009). Nevertheless, again we ran robustness checks which additionally account for partially owned subsidiaries in the calculation of $t d_{i t}$ and did not find our empirical results to be sensitive with respect to this modification.

As shown in Table 2a, both the statutory tax rate as well as the constructed tax difference measure $t d_{i t}$ exhibit considerable variation across our sample observations. The average statutory tax rate is $37.7 \%$ and it varies between $10 \%$ and $59 \%$ for the firms in our sample. The average tax difference is $0 \%$ and exhibits a wide spread between $-30.5 \%$ and $37.5 \%$.

Third, we add information on withholding rates which apply on royalties payments to a subsidiary in our sample. Royalty withholding rates are specified in bilateral tax treaties. If a bilateral tax treaty does not exist, countries usually impose a unilateral rate which holds for royalty payments to all non-treaty countries. Since the unilateral rates are generally higher than the treaty rates, countries with a favorable treaty network are expected to be attractive patent locations. We retrieve information on the unilateral royalty withholding rates as well as information on treaty withholding rates from the Ernest \& Young corporate tax guides 1995-2003.

This information allows us to calculate a tax measure $t e_{i t}$ which captures the effective tax burden on royalty income earned by patents held at a given multinational subsidiary. As described in Section 2, this effective tax rate on royalty income is calculated as the maximum of the statutory tax rate applicable at the income-receiving subsidiary and the withholding tax rate applicable on the royalty income stream. To calculate this effective tax burden in our data set, we have to make an assumption about the nature of the royalty streams earned by a patent-holding subsidiary in our sample. As patents are widely acknowledged to be common goods within a multinational firm 
which are employed as input factor by several operating affiliates (see Markusen, 1995), we will assume that a patent-holding subsidiary receives royalty income from all other affiliates within its multinational group, including the parent. ${ }^{13}$ Therefore, to calculate the effective tax rate for a considered subsidiary, we determine the maximum of the subsidiary's statutory tax rate and the withholding tax rate applicable if royalties are paid from a foreign affiliate to the considered subsidiary and take the unweighted average of these measures. Again, we account for wholly owned affiliates only. Formally, this is captured by

$$
t e_{i t}=\sum_{j} \frac{1}{N} \max \left(t_{i t}, w h t_{i, j, t}\right), \quad i \neq j
$$

whereas $w h t_{i, j, t}$ depicts the withholding tax rate applicable on royalty income paid by the foreign affiliate $j$ to the considered subsidiary $i$. Again, we determine an unweighted average of the royalty withholding rates and restrict the calculation in (2) to foreign affiliates which are either the considered subsidiary's parent or are wholly owned by the multinational group. In robustness checks, we relaxed these assumptions and did not find our qualitative results to be affected.

Table $2 \mathrm{~b}$ exhibits the withholding tax rates on royalty income applicable in 2003 between EU countries, the US and Japan. The table indicates that withholding tax rates are usually low, being zero in many cases. High rates mostly apply for royalty payments involving Eastern and Southern European member states, the US and Japan. ${ }^{14}$ Moreover, the multinational groups in our sample comprise several non-EU subsidiaries whose host countries do not have tax treaties with the European economies in our sample and thus charge unilateral withholding rates which are well above $20 \%$. As presented in the sample statistics in Table 2a, the average withholding tax rates charged on royalty streams from foreign group members to our sample subsidiaries vary between $0 \%$ and $30 \%$, but the average rate is only $1.1 \%$. Thus it is not surprising to find that the calculation of the effective tax rate $t e_{i t}$ is largely dominated by the statutory tax measure as the withholding tax is usually lower than the host country's corporate tax. The average rate is $35.5 \%$ and varies between a minimum of $10 \%$ and a maximum rate of $59 \% .^{15}$

\footnotetext{
${ }^{13}$ Thus, we implicitly assume that patent(s) held at the considered subsidiary are used by all other affiliates within the group and that royalties are paid for the use of this patent.

${ }^{14}$ Note, that after our sample period in 2004 the EU Interest and Royalty Directive took effect which abolished withholding tax rates between countries in the European Union.

${ }^{15}$ Note that the average effective tax rate calculated for our sample is slightly smaller than the
} 
Last, we construct a CFC dummy variable which indicates whether CFC legislations are binding for a subsidiary in a given year. The information on CFC legislations is collected from Sandler (1998), Lang et al. (2004) and the International Bureau of Fiscal Documentation (IBFD). ${ }^{16}$ As described in the previous section, for CFC rules to be binding, they have to be implemented in the subsidiary's parent country and three additional criteria have to be fulfilled: First, the parent firm has to hold a sufficiently large ownership share in the subsidiary. Second, the income derived in the subsidiary has to be mainly passive in nature. Third, the subsidiary's host economy has to be classified as a tax haven by its parent country.

Since the subsidiaries in our sample are ultimately owned by their parent firms and the ownership thresholds in CFC legislations are usually low (at 10\%), the ownership criterion is fulfilled for all affiliates in our sample. Moreover, royalty income earned on patents is one potential source of passive income in a subsidiary since it often does not relate to other active parts of the business, and hence we equally assume the passive income criterion is fulfilled. Consequently, the construction of our CFC dummy variable will focus on the tax haven criteria which are summarized in Table 2c for the most important parent countries in our sample. As depicted in the table, the tax haven criteria are fulfilled if the subsidiary's host country is on a black list at the parent location or exhibits a corporate tax rate that falls short of a defined threshold. Since many of the subsidiaries in our sample are located in European high-tax countries, CFC rules do not apply in their context. Thus, it is not surprising that the fraction of observations in our sample for which CFC rules are binding is only 6.4\%. As shown in Table $2 \mathrm{~d}, \mathrm{CFC}$ legislations are most likely to apply if the parent firm resides in the US, Canada and Germany. In turn, the subsidiaries for which CFC rules are likely to be binding tend to be located in countries with low tax rates, such as Ireland and Switzerland (in which $43 \%$ and $20 \%$ of the sample subsidiaries face binding CFC rules, see the last column of Table 2c).

Note, however, that our constructed measure for a binding CFC rule is only a proxy.

average statutory tax rate. Theoretically, the statutory tax rate measure should be a lower bound for the effective tax rate measure which is the maximum of the statutory and the withholding rate on royalty income. However, the effective tax rate measure can only be calculated for the subset of our sample affiliates for which ownership information on the multinational group is available, which overproportionally tends to be the case for sample subsidiaries with a low corporate tax rate and henceforth also a low effective tax rate measure.

${ }^{16}$ We collected information on CFC legislations for all major parent countries in our sample (i.e. EU25, the US, Canada, Japan and Korea). As a small number of firms in our sample observe parents located in other countries, the CFC legislation is missing for a small fraction of the observations. 
One issue may for example be that there is a considerable number of US owned European subsidiaries in our sample which we classify as being subject to CFC treatment. But in practice US multinationals may opt out of CFC treatment under so-called "check the box" rules. Since we cannot track which of the European subsidiaries of US parents have been elected to "check the box" treatment, we assume they are all subject to the usual CFC treatment. As this might not hold for all cases, we introduce noise to our estimation which is expected to bias our coefficient estimates towards zero. Henceforth, if we find significant effects of CFC rules on patent ownership, they should be interpreted as the lower bound to the true impact.

Moreover, Table 2 a reports summary statistics for the size of the firms included in our sample. The size measures vary strongly across the companies in our sample with an average employment number of 1, 408 but a relatively large standard deviation from the mean. The same applies for the fixed asset variable. Additionally, we add information on time-varying country characteristics which we presume to influence the location of corporate patents, precisely the number of scientific researchers per million of country inhabitants and the gross domestic product (GDP) (both obtained from the World Development Indicator database). The average subsidiary in our sample is located in a country with a GDP of 1.4 trillions US dollars and 2,918 scientific researchers per million of country inhabitants.

\section{Estimation Methodology}

The aim of our analysis is to determine if and to what extent corporate taxation impacts on the location of patents within a multinational group. The analysis focuses on the tax determinants of the number of patent applications by a multinational subsidiary $i$ in year $t$. Precisely, we estimate a model of the following form

$$
y_{i t}=\beta_{1} T_{i t}+\beta_{2} X_{i t}+\theta_{i}+\rho_{t}+\epsilon_{i, t}
$$

whereas $y_{i, t}$ depicts subsidiary $i$ 's number of patent applications at time $t$ which is regressed on a vector of corporate tax parameters $T_{i, t}$ comprising the variables constructed in the previous Sections 2 and 3: the host country's statutory tax rate $t_{i t}$, the tax rate difference between the considered affiliate and other group members $t d_{i t}$, an effective tax rate on royalty income which takes into account the corporate tax rate and the withholding rates on royalty income $t e_{i t}$ and last, a dummy variable $C F C_{i t}$ which indicates whether CFC rules apply. We expect all these variables to decrease 
the number of patents held by a subsidiary and hence the estimated coefficients on the regressors are expected to be negative $\left(\beta_{1}<0\right)$.

Moreover, we include a set of control variables into our analysis which is depicted by the vector $X_{i t}$. First, we account for affiliate size to ensure that the coefficient estimates for $\beta_{1}$ do not only reflect the well-known negative effect of corporate taxes on firm size. Precisely, we include the number of employees as a size control whereas sensitivity checks show that the results are robust against the use of other size variables like fixed asset investment. Moreover, we account for the country's attractiveness as an R\&D location and its market size by including control variables for the number of scientific researchers per inhabitants and the country's GDP. ${ }^{17}$ However, the attractiveness of a subsidiary as a patent location is also likely to be determined by affiliate specific factors which are unobservable to the econometrician. This suggests to include a set of affiliate fixed effects $\theta_{i}$ to capture time-constant firm differences which is also confirmed by a Hausman test. Last, we include a full set of year fixed effects $\rho_{t}$ to control for shocks over time that are common to all subsidiaries and (in robustness checks) add a full set of 2-digit industry-year dummies to account for industry-specific shocks over time.

In the first set of regressions, we estimate equation (3) in a simple OLS framework with firm fixed effects. The OLS approach however does not account for the fact that the patent variable is restricted to positive values. We thus in a second step reestimate equation (3) in models which account for censored data. ${ }^{18}$ In the following, we will present the results of a random effects tobit framework. Note that the estimation of a fixed effect tobit model is not feasible as a sufficient statistic that allows the fixed effect to be conditioned out of the likelihood does not exist. We however allow for a correlation between the subsidiary specific effects and the explanatory variables in the random effects specifications following Mundlak (1978) and Chamberlain (1984) by explicitly modelling this correlation and assuming a particular parameterization of the firm specific effect as a function of the explanatory variables. Precisely, we adapt an often made choice in this context and model the affiliate fixed effect as a linear combination of the explanatory variables' averages over time.

Nevertheless, our most preferred model is a negative binomial framework as it does consider the count nature of our data and the skewed distribution in the number of

\footnotetext{
${ }^{17}$ In robustness checks, we moreover experimented with including additional country characteristics and did not find our results to be affected (see Section 5).

${ }^{18}$ Note that the number of patent counts may become negative if multinationals, for example, withdraw patent applications or file a technology developed at a considered subsidiary with another affiliate. As these cases are reported as zero counts, our data may be considered as censored.
} 
patent counts. The negative binomial specifications are thereby chosen since a likelihood ratio test indicates overdispersion of our data and suggests that the model cannot be collapsed to a poisson specification (although poisson estimations derive qualitatively comparable results). Precisely, we follow Hausman et al. (1984) and estimate a negative binomial regression model which accounts for firm specific effects.

\section{Results}

Our results are presented in Tables 3 to 6 . All regressions account for subsidiary and year fixed effects. Heteroscedasticity robust standard errors which control for clustering at the firm level are depicted in parentheses below the coefficient estimates.

Table 3 presents regressions of the number of patent applications on the host country's corporate tax rate. Specifications (1) to (3) depict OLS estimates with subsidiary fixed effects. In line with the intuition described in Section 2, we find that the corporate tax rate exerts a significantly negative impact on the subsidiaries' number of patent applications. This effect turns out to be robust against the inclusion of time-varying country controls in Specification (2) and a size control in Specification (3). Evaluated at the sample mean, Specification (3) suggests that an increase in the corporate tax rate by 1 percentage point reduces the number of patent applications by $2.8 \%$.

Specifications (4) to (6) moreover account for the restriction of the patent variable to positive values and reestimate the link between corporate taxes and patent applications in a random effects tobit model which includes time-averages of the regressors to control for time-invariant subsidiary characteristics. The results confirm our previous findings and indicate a negative effect of corporate taxes on the number of patent applications which is robust against the inclusion of time-varying country characteristics and a size control in Specifications (5) and (6). The OLS effect is also quantitatively confirmed as Specification (6) suggests that an increase in the corporate tax rate by 1 percentage point reduces the number of patent applications by $2.9 \% .{ }^{19}$

However, as mentioned in the previous section, our most preferred specification is a negative binomial model which controls for time-constant subsidiary characteristics

19 Note that the coefficient estimates in the random effects tobit model (presented in Specifications (4) to (6)) have no direct quantitative interpretation. To quantitatively interpret the results, we assume the random effect to be zero and calculate the marginal effect for the expected value of the patent application variable conditional on being uncensored. For the specification in Column (6), we derive a marginal effect of -2.01 . Evaluated at the sample mean, this translates into a semi-elasticity of -2.9 . 
as this acknowledges the count nature of our data and the skewness in the patent count distribution. The negative binomial framework is chosen as a likelihood ratio test indicates overdispersion of the data and rejects the estimation of a poisson model (the likelihood ratio chi-square statistic for the baseline specification in Column (7) is 799.65; if control variables are included in the specifications, the chi-square statistic increases further). The results are presented in Specifications (7) to (9) and confirm our previous findings as the corporate tax rate exerts a significant and negative impact on the number of patent applications. Interpreting the coefficient estimates quantitatively in this fixed effects framework is not straight forward (as the common assumption of a zero fixed effect implies an implausible expected patent count of zero in this model). We thus reestimate the specifications in a random effects negative binomial specification which models fixed effects by time-averages of the regressors (whereas the results are not reported in the paper but available from the authors upon request). Evaluated at a random effect of zero (which is noncritical in the random-effect framework, see e.g. Winkelmann, 2008), this model derives comparable quantitative results to the ones reported in the OLS and tobit specifications.

The number of patent applications might, however, not only be dependent on the statutory tax rate applicable in a country but may also be determined by alternative location options within the multinational group. To account for that, we constructed an alternative tax measure which captures the average difference between a subsidiary's statutory tax rate and the statutory tax rate at other group locations as described in Section 3. Since the construction of the tax difference measure requires information on the ownership structure of the multinational group which is available for a subset of firms in our sample only, the sample size drops compared to our baseline estimations. The results are presented in Table 4 and suggest a negative impact of the corporate tax rate differential on the number of patent applications which is robust against different model specifications and the inclusion of size and time-varying country-controls. Quantitatively, the findings largely resemble the results for the corporate tax rate measure presented in the previous table. The tobit specification in Column (6) suggests that an increase in the corporate tax rate differential by 1 percentage point reduces the number of patent applications by $2.3 \%$ (see also footnote 19 ).

So far, our analysis has only accounted for effects of statutory corporate tax rate measures. However, as explained in the previous sections, the location of patents within a multinational firm may equally be determined by royalty withholding taxes which motivates the construction of an effective tax measure that takes both, the statutory and the withholding tax rate, into account. Since the calculation of this tax measure 
requires information on the MNE's ownership structure (see Section 3), the sample size again falls short of the baseline estimations. The results are presented in Table 5. Specifications (1) to (9) indicate that the constructed effective tax measure exerts a significantly negative effect on the number of patent applications which prevails in different model frameworks and is robust against the inclusion of size and country controls. In quantitative terms, the results are comparable to our baseline estimations.

In Column (10), we moreover determine the effect of the statutory tax rate and the withholding tax rate separately from each other in the negative binomial framework. While the statutory tax rate as in previous specifications has a strong and negative impact on the number of patent applications, the withholding tax rate on royalty income does not exert a statistically significant effect. This reflects that withholding tax rates are usually smaller than the corporate income tax due on the royalty income stream which triggers a full rebate for the withholding taxes paid. Taking this into account, it is not surprising that withholding taxes do not in general exert a significant effect on the patent location decision.

Apart from that, we assess whether a binding CFC regulation affects the number of patent applications. We thus reestimate the baseline specifications in Table 3 and include a dummy variable which indicates whether the patent owning subsidiary is likely to be subject to CFC treatment in the parent country (see Section 3 on the construction of the variable). The results are presented in Table 6. The OLS specifications depicted in Columns (1) to (3) suggest that the corporate tax rate exerts a negative effect on the number of patent applications while the coefficient estimate for the CFC legislation dummy, however, does not gain statistical significance. This is confirmed by estimations of a random effects tobit model presented in Columns (4) to (6).

Nevertheless, as laid out in the previous section, our most preferred estimation model is a negative binomial framework which accounts for subsidiary fixed effects. The results of these specifications are presented in Columns (7) to (9). Interestingly, the count data model in line with our hypothesis suggests that a binding CFC rule reduces the number of patents located at a subsidiary (see Column (7)) whereas this effect is also robust against the inclusion of control variables for subsidiary size and country characteristics (see Columns (8) and (9)). Thus, taking into account the count nature and overdispersion of our data, we find evidence that binding CFC legislations are effective in reducing the number of patent applications (and the associated, potentially passive, income streams).

Finally, we ran a set of robustness checks. First, we reestimated all our specifications 
controlling for a full set of 2-digit industry-year effects to absorb industry shocks over time and find comparable results to the ones reported in this paper. Moreover, we experimented with different variables to control for affiliate size (e.g. subsidiary assets) and additional country controls (e.g. a corruption index and the national unemployment rate) which leaves the results unchanged. Last, we accounted for the fact that a large fraction of subsidiary-year combinations report zero patent applications and additionally estimated a binary logit model which controls for subsidiary fixed effects. These specifications derive qualitatively comparable results which are reported in an earlier working paper version of this paper (Karkinsky and Riedel, 2009).

\section{Conclusion and Discussion}

Anecdotal evidence suggests that patents and other intangible assets play a decisive role in profit shifting strategies of multinational enterprises. Several firms are known to hold their patents and trademarks in tax-haven countries like Ireland and Switzerland, famous examples are Vodafone, Pfizer and Microsoft. Although tax authorities in various countries have raised increasing concerns about these intangibles relocations, studies which tests for the link between corporate taxes and intangible assets in a systematic empirical framework are scarce.

This paper exploits a new and unique data set which links company accounting data to information on patent applications provided by the European Patent Office in order to investigate whether and to what extent corporate taxation affects the patent location within multinational groups. Our results suggest that the corporate tax rate exerts a strong negative impact on a subsidiary's number of patent applications. The effect appears across a range of model specifications and is robust against controlling for affiliate size, firm fixed effects and time-varying country characteristics. Similar findings are reported if we account for the relative attractiveness of a subsidiary's tax scheme by using the tax rate differential to other group members as explanatory variable. Moreover, the estimated effects prevail if we additionally account for the role of withholding taxes on royalty payments.

Thus, our findings indeed suggest that MNEs tend to distort the location of their corporate patents in favor of low-tax affiliates. As patented technologies are considered to be drivers of future profits and a major souce of transfer pricing opportunities within multinational groups, their relocations are likely to shift relevant volumes of profit to low-tax economies. Consequently, governments have an incentive to compete for these 
mobile profits by reducing their corporate tax rates in order to attract multinational patents to their jurisdiction. Recent tax policy changes in some countries suggest that this is already taking place as Ireland, the Netherlands, Belgium and Luxembourg have recently introduced special low tax rates on royalty income from patents.

This in turn puts pressure on high-tax economies with large R\&D activities to restrict the mitigation of patents and other intangible assets from their borders. One mean to limit this outflow is to introduce or tighten $\mathrm{CFC}$ legislations which make foreign royalty income taxable at the parent location. Examples of countries which recently introduced CFC rules are Spain and Italy. Moreover, our empirical results suggest that CFC legislations are indeed effective in restricting patent relocations as binding CFC clauses are reported to exert a negative impact on the number of patent applications. Furthermore, several countries currently consider to restrict intangibles relocations via the introduction of a second anti-avoidance instrument. In 2008, Germany as the first economy implemented a new legislation which aims to tax part of the future income generated from patents and other (intangible) assets developed in Germany even after their relocation to a foreign country (see OECD (2009) for details). Practitionners suggest that other countries might implement similar legislations soon. In the light of our results, these policy moves to limit the (re)location of patents and other intangible assets to low-tax economies are highly welcome as they help to close an important profit shifting channel and therefore to reduce international tax competition behaviour. 


\section{$7 \quad$ References}

Abramovsky, L., R. Griffith, G. Macartney and H. Miller (2008), The Location of Innovative Activity in Europe, The Institute of Fiscal Studies WP 08/10.

Bloom, N., R. Griffith and J. van Reenen (2002), Do R\&D Tax Credits Work? Evidence from a Panel of Countries 1979-1997, Journal of Public Economics 85, 1-31.

Branstetter L.G., R. Fisman and C.F. Foley (2006), Do Stronger Intellectual Property Rights Increase International Technology Transfer? Empirical Evidence from US Firm-Level Panel Data, Quarterly Journal of Economics 121(1), 321-349.

Chamberlain, G. (1980), Analysis of Covariance with Qualitative Data, Review of Economic Studies 47, pp. 225-238.

Chamberlain, G. (1984), Panel Data, in Z. Griliches and M.D. Intriligator (eds), Handbook of Econometrics, Vol. II, North-Holland, Amsterdam, 1247-1318.

Clausing, K. A. (2003), Tax-Motivated Transfer Pricing and US Intrafirm Trade Prices, Journal of Public Economics 87(3), 2207-2223.

Devereux, M.P. (2007), The Impact of Taxation on the Location of Capital, Firms and Profit: a Survey of Empirical Evidence, CBT Working Paper 07/02.

Dischinger, M. and N. Riedel (2008), Corporate Taxes and the Location of Intangible Assets within Multinational Firms, Munich Economics Discussion Papers No. 2008-15.

Ethier, W. J. and J. R. Markusen (1996), Multinational Firms, Technology Diffusion and Trade, Journal of International Economics 41(1), 1-28.

Fosfuri, A. (2000), Patent Protection, Imitation and the Mode of Technology Transfer, International Journal of Industrial Organization 18(7), 1129-1149.

Gattai, V. and C. Molteni (2007), Dissipation of Knowledge and the Boundaries of the Multinational Enterprise, Review of World Economics, 143(1), 1-26.

Greene, W. H. (2008), Econometric Analysis, Prentice-Hall, New York.

Grubert, H. (1998), Taxes and the Division of Foreign Operating Earnings Among Royalties, Interest, Dividends and Retained Earnings, Journal of Public Economics 68(2), 269-290. 
Grubert, H. (2003), Intangible Income, Intercompany Transactions, Income Shifting and the Choice of Location, National Tax Journal 56 (1), 221-42.

Hall, B. H. (1993), R\&D Tax Policy During the Eighties: Success or Failure?, Tax Policy and the Economy 7, 1-36.

Hall, B. H. (2000), Innovation and Market Value, in: R. Barrell, G. Mason and M. O'Mahoney (eds), Productivity, Innovation and Economic Performance, Cambridge, Cambridge University Press, 188-98.

Hall, B. H. (2007), Measuring the Returns to R\&D: The Depreciation Problem, working paper.

Hall, B. H., A. B. Jaffe, and M. Trajtenberg (2005), Market Value and Patent Citations, Rand Journal of Economics 36, 16-38.

Hall, R. E. (2001), The Stock Market and Capital Accumulation, The American Economic Review 91(5), 1185-1202.

Hausman, J., B. H. Hall and Z. Griliches (1984), Econometric Models for Count Data with an Application to the Patents-R\&D Relationship, Econometrica 52, 909-938.

Hejazi, J. (2006), Assessing the Risks of Intangibles Migration, Tax Management - Transfer Pricing, 15(10), 399-401.

Hines, J. R. (1994), No Place Like Home: Tax Incentives and the Location of R\&D by American Multinationals. Tax Policy and the Economy 8, 65-104.

Hines J.R. (ed.) (2001), International Taxation and Multinational Activity, Chicago: University of Chicago Press, 201-226.

Hines J. R. and A. B. Jaffe (2001), International Taxation and the Location of Inventive Activity, in: Hines, J. R. (ed) (2001), International Taxation and Multinational Activity, University of Chicago Press.

Huizinga, H., and L. Laeven (2008), International Profit Shifting Within Multinationals: A MultiCountry Perspective, Journal of Public Economics 92(5-6), 1164-1182.

Karkinsky, T. and N. Riedel (2009), Corporate Taxation and the Choice of Patent Location within Multinational Firms, Oxford University Centre for Business Taxation, Working Paper 09/14. 
Lang, M., H.-J. Aigner, U. Scheuerle, M. Stefaner (2004), CFC Legislation, Tax Treaties And EC Law, Kluwer Law International.

Markusen, J. R. (1995), The Boundaries of Multinational Enterprises and the Theory of International Trade, Journal of Economic Perspectives, 9, 169-189.

Markusen, J. R. (2001), Contracts, Intellectual Property Rights and Multinational Investment in Developing Countries, Journal of International Economics 53(1), 189-204.

Mutti, J. and H. Grubert (2008), The Effect of Taxes on Royalties and the Migration of Intangible Assets Abroad (Jan 2008), Paper prepared for the NBER/CRIW Conference on International Service Flows.

Mundlak, Y. (1978), On the Pooling of Time Series and Cross Section Data, Econometrica, 46, 6986.

OECD (2009), Transfer Pricing Aspects of Business Restructurings - Discussion Draft for Public Comment.

Saggi, K. (1996), Entry Into a Foreign Market: Foreign Direct Investment Vs. Licensing, Review of International Economics 4(1), 99-104.

Saggi, K. (1999), Foreign Direct Investment, Licensing and Incentives for Innovation, Review of International Economics 7(4), 699-714.

Sandler, D. (1998), Tax Treaties and Controlled Foreign Company Legislation: Pushing the Boundaries, Springer.

The Guardian (2009), Offshore and Out of Reach to the Revenue, February 3, 2009.

Wallstreet Journal (2005), Irish Subsidiary Lets Microsoft Slash Taxes in U.S. and Europe, November 5,2005 .

Weichenrieder, A. (2009), Profit Shifting in the EU: Evidence from Germany, International Tax and Public Finance 16, pp. 197-281.

Winkelmann, R. (2008), Econometric Analysis of Count Data, 5th Edition, Springer-Verlag Berlin.

Zingales, L. (2000), In Search of New Foundations, Journal of Finance 55(4), pp. 1623-1653. 


\section{Appendix: Tables}

\begin{tabular}{|l|c|c|}
\hline \multicolumn{3}{|c|}{ Table 1: Country Statistics } \\
\hline \hline Country & Subsidiary Location & Parent Location \\
\hline Belgium & 266 & 356 \\
Czech Republic & 8 & 1 \\
Denmark & 588 & 579 \\
Finland & 162 & 180 \\
France & 1,527 & 1,320 \\
Germany & 2,984 & 2,317 \\
Great Britain & 2,812 & 1,991 \\
Greece & 2 & 4 \\
Ireland & 87 & 56 \\
Italy & 515 & 452 \\
Luxembourg & 29 & 43 \\
Netherlands & 944 & 1,080 \\
Norway & 222 & 209 \\
Poland & 7 & 1 \\
Portugal & 11 & 12 \\
Spain & 324 & 256 \\
Sweden & 838 & 881 \\
Switzerland & 502 & 546 \\
Austria & - & 89 \\
Canada & - & 49 \\
Japan & - & 136 \\
United States & - & 1,057 \\
Others & - & 213 \\
\hline Sum & 11,828 & 11,828 \\
\hline
\end{tabular}




\begin{tabular}{|l|ccccc|}
\hline \multicolumn{7}{|c|}{ Table 2a: Descriptive Statistics } \\
\hline \hline Variable & Obs. & Mean & Median & Min. & Max. \\
\hline Number of Patents & 85,330 & .706 & 0 & 0 & 20 \\
Dummy for Patent Ownership & 85,330 & .281 & 0 & 0 & 1 \\
& & & & & \\
Statutory Tax Rate & 85,330 & .377 & .35 & 0.1 & .59 \\
Tax Rate Difference & 28,939 & .009 & 0 & -.305 & .375 \\
Effective Tax Rate & 27,074 & .355 & .31 & .1 & .59 \\
Withholding Tax Rate & 27,074 & 0.011 & 0 & 0 & .3 \\
Binding CFC Legislation & 85,192 & .064 & 0 & 0 & 1 \\
& & & & & \\
Number of Researchers & 85,330 & $2,915.985$ & $2,873.071$ & $1,014.0$ & $7,998.24$ \\
GDP & 85,330 & $1,347.569$ & 705.441 & 20.329 & $2,446.885$ \\
Number of Employees & & & & & \\
Fixed Assets & 14,322 & $1,066.496$ & 277 & 1 & 92,916 \\
\hline
\end{tabular}

Notes:

- Takes on the value 1 if a subsidiary observes a positive number of patents applications in a considered year, 0 otherwise.

- Per million people

$\star$ In billion of US dollars.

- In thousands of US dollars. 


\begin{tabular}{|c|c|c|}
\hline & & 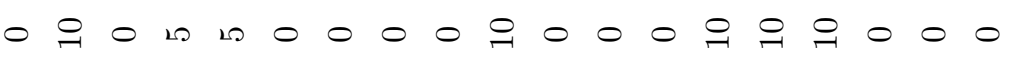 \\
\hline & E & 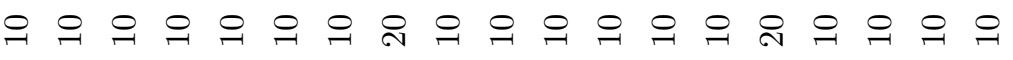 \\
\hline & 0 & 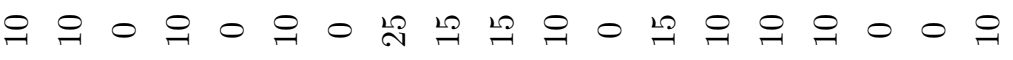 \\
\hline & 穵 & 0100000000000001010010 \\
\hline & & 000000000000000000 \\
\hline & 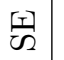 & 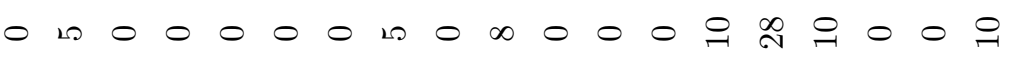 \\
\hline & & 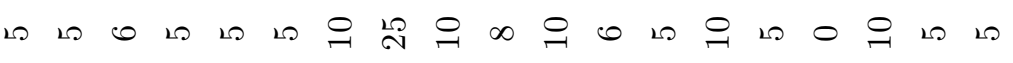 \\
\hline$\approx$ & 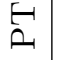 & 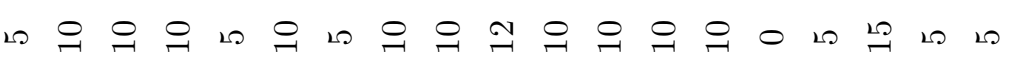 \\
\hline & 官 & 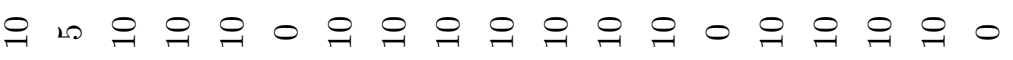 \\
\hline & O & 0000000000000000000 \\
\hline 赵 & 安 & 0000000000000000000 \\
\hline ع & 兒 & 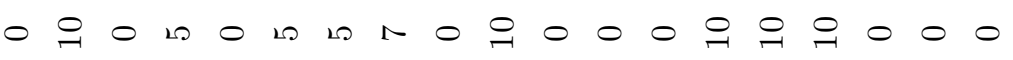 \\
\hline & $\Xi$ & 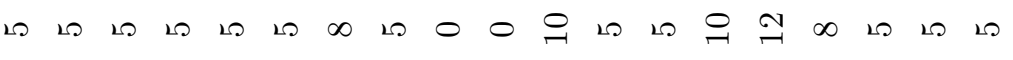 \\
\hline$\stackrel{ \pm}{\sigma}$ & 国 & 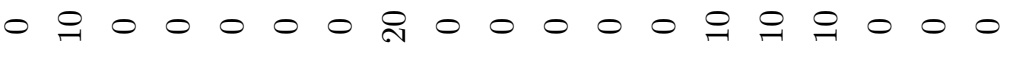 \\
\hline 5 & ซै & 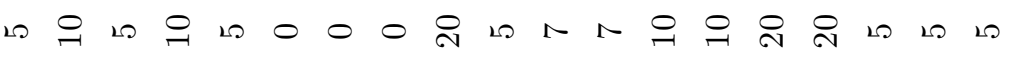 \\
\hline & 원 & $000000000 \infty 1000100000$ \\
\hline & 㲁 & 010010000000101000001000 \\
\hline & & 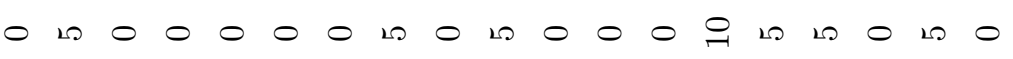 \\
\hline & ( & 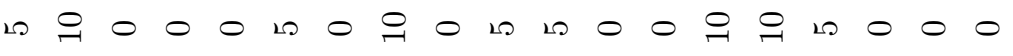 \\
\hline & 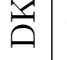 & 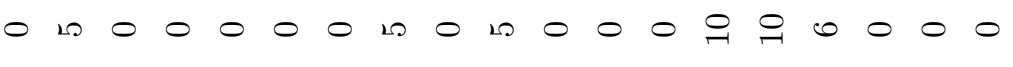 \\
\hline & $N$ & $100101010 \quad 10 \%$ \\
\hline & $\frac{T}{M}$ & $0100100001000000 \% 1010000$ \\
\hline & & \\
\hline
\end{tabular}




\begin{tabular}{|l|c|c|}
\hline \multicolumn{3}{|c|}{ Table 2c: CFC Legislation in 2003 } \\
\hline \hline Country & CFC Dummy & Tax Haven Definition \\
\hline Belgium & 0 & - \\
Czech Republic & 0 & - \\
Denmark & 1 & Effective tax $<75 \%$ of Danish Tax \\
Finland & 1 & Effective tax $<60 \%$ of Finish Tax \\
France & 1 & Effective tax $<66 \%$ of French Tax \\
Germany & 1 & Effective tax $<25 \%$ \\
Great Britain & 1 & Effective tax $<75 \%$ of British Tax \\
Greece & 0 & - \\
Ireland & 0 & - \\
Italy & 1 & - \\
Luxembourg & 0 & - \\
Netherlands & 0 & - \\
Norway & 1 & Elack List \\
Poland & 0 & - \\
Portugal & 1 & Effective tax $<60 \%$ of Portugese Tax \\
Spain & 1 & Effective tax $<75 \%$ of Spanish Tax \\
Sweden & 1 & Effective tax $<55 \%$ of Swedish Tax \\
Switzerland & 0 & - \\
Austria & 0 & Always Binding \\
Canada & 1 & Effective tax $<75 \%$ of US Tax \\
Japan & 1 & \\
United States & 1 & - \\
\hline
\end{tabular}

Notes:

CFC Dummy takes on the value 1 if the parent country has a CFC legislation and the value 0 otherwise. In the case of Norway, the $66 \%$ rule does not apply if a bilateral tax treaty exists between Norway and the country of the controlled subsidiary, unless the majority of the income in that subsidiary is passive. We use our data on royalty withholding rates to determine whether a bilateral tax treaty exists. In the case of Italy the black list of tax havens is quite long to be listed here, but it is based on and is very similar to the OECD tax haven list. 


\begin{tabular}{|l|c|c|c|}
\hline \multicolumn{4}{|c|}{ Table 2d: Binding CFC Legislation } \\
\hline \hline Country & Parent-Year & Subsidiary-Year (in \#) & Subsidiary-Year (in \%) \\
\hline Belgium & 0 & 8 & 0.34 \\
Czech Republic & 0 & 0 & 0 \\
Denmark & 12 & 138 & 3.91 \\
Finland & 16 & 36 & 3.20 \\
France & 24 & 326 & 2.69 \\
Germany & 139 & 48 & 0.20 \\
Great Britain & 56 & 3,725 & 16.61 \\
Greece & 0 & 0 & 0 \\
Ireland & 0 & 296 & 42.53 \\
Italy & 5 & 24 & 0.59 \\
Luxembourg & 0 & 2 & 3.51 \\
Netherlands & 0 & 335 & 4.45 \\
Norway & 0 & 34 & 3.83 \\
Poland & 0 & 5 & 8.93 \\
Portugal & 0 & 0 & 0 \\
Spain & 2 & 134 & 5.17 \\
Sweden & 16 & 154 & 4.62 \\
Switzerland & 0 & 204 & 20.46 \\
Austria & 0 & - & - \\
Canada & 379 & - & - \\
Japan & 0 & - & - \\
United States & 469 & 5,469 & - \\
\hline Sum & & & - \\
\hline
\end{tabular}

Notes:

The parent-year column depicts the parent countries for the subsidiary-year observations which face binding CFC rules. The subsidiary-year column (in \#) presents the country distribution for the subsidiary-year observations which face binding CFC rules. Analogously, the last column (subsidiary-year (in \%)) indicates the percentage of the subsidiary-year observations per country which face binding CFC rules. 


\begin{tabular}{|c|c|c|c|c|c|c|c|c|c|}
\hline \multicolumn{10}{|c|}{$\begin{array}{l}\text { Table 3: Effects of the Statutory Tax Rate } \\
\text { Panel 1995-2003 }\end{array}$} \\
\hline Model & \multicolumn{3}{|c|}{ FE OLS } & \multicolumn{3}{|c|}{ RE Tobit } & \multicolumn{3}{|c|}{ FE Negative Binomial Model } \\
\hline Explanat. Var.: & (1) & (2) & (3) & (4) & (5) & (6) & (7) & (8) & (9) \\
\hline Statutory Tax Rate & $\begin{array}{c}-1.751^{* * *} \\
(.194)\end{array}$ & $\begin{array}{c}-1.130^{* * *} \\
(.201)\end{array}$ & $\begin{array}{l}-2.025^{*} \\
(1.100)\end{array}$ & $\begin{array}{c}-4.654^{* * *} \\
(.447)\end{array}$ & $\begin{array}{c}-3.066^{* * *} \\
(.567)\end{array}$ & $\begin{array}{c}-4.885^{* * *} \\
(1.710)\end{array}$ & $\begin{array}{c}-677^{* * *} \\
(.195)\end{array}$ & $\begin{array}{c}.939^{* * *} \\
(.221)\end{array}$ & $\begin{array}{c}-1.241^{* * *} \\
(.402)\end{array}$ \\
\hline Log \# Researchers & & $\begin{array}{c}.299^{* * *} \\
(.098)\end{array}$ & $\begin{array}{l}.020 \\
(.448)\end{array}$ & & $\begin{array}{c}1.651^{* * *} \\
(.374)\end{array}$ & $\begin{array}{l}.822 \\
(.710)\end{array}$ & & $\begin{array}{c}.193^{* * *} \\
(.097)\end{array}$ & $\begin{array}{l}.184 \\
(.210)\end{array}$ \\
\hline Log GDP & & $\begin{array}{c}-.752^{* * *} \\
(.096)\end{array}$ & $\begin{array}{c}-1.776^{* * *} \\
(.563)\end{array}$ & & $\begin{array}{c}-2.187^{* * *} \\
(.347)\end{array}$ & $\begin{array}{c}-1.681^{* * *} \\
(.668)\end{array}$ & & $\begin{array}{l}.100^{* *} \\
(.041)\end{array}$ & $\begin{array}{c}.419^{* * *} \\
(.092)\end{array}$ \\
\hline Log Employees & & & $\begin{array}{c}.194^{* * *} \\
(.048)\end{array}$ & & & $\begin{array}{c}.437^{* * *} \\
(.096)\end{array}$ & & & $\begin{array}{c}.094^{* * *} \\
(.026)\end{array}$ \\
\hline Year Dummies & $\sqrt{ }$ & $\sqrt{ }$ & $\sqrt{ }$ & $\sqrt{ }$ & $\sqrt{ }$ & $\sqrt{ }$ & $\sqrt{ }$ & $\sqrt{ }$ & $\sqrt{ }$ \\
\hline Time Avg. Expl. V. & & & & $\sqrt{ }$ & $\sqrt{ }$ & $\sqrt{ }$ & & & \\
\hline \# Observations & 85,330 & 85,330 & 12,033 & 85,330 & 85,330 & 12,033 & 79,768 & 79,768 & 9,841 \\
\hline \# Firms & 11,828 & 11,828 & 3,888 & 11,828 & 11,828 & 3,888 & 10,738 & 10,738 & 2,315 \\
\hline
\end{tabular}

Notes:

Heteroscedasticity robust standard errors adjusted for firm clusters in parentheses. ${ }^{*},{ }^{* *},{ }^{* * *}$ indicates significance at the $10 \%, 5 \%, 1 \%$ level. The observational units are multinational subsidiaries per sample year. All regressions include a full set of firm fixed effects. The dependent variable is the number of patents located at a multinational subsidiary. Statutory Tax Rate depicts the statutory tax rate applicable in the subsidiaries' host country. Log \# Researchers stands for the natural logarithm of the number of scientific researchers in a country, Log GDP is the natural logarithm of the gross domestic product. Log Employees depicts the natural logarithm ( $\log )$ of the firm's number of employees. FE and RE indicate fixed effect and random effect specifications respectively. Time Avg. Expl. V. indicates that time averaged explanatory variables are included in the estimation. 


\begin{tabular}{|c|c|c|c|c|c|c|c|c|c|}
\hline \multicolumn{10}{|c|}{$\begin{array}{l}\text { Table 4: Effects of the Statutory Tax Rate Difference } \\
\text { Panel 1995-2003 }\end{array}$} \\
\hline Model & \multicolumn{3}{|c|}{ FE OLS } & \multicolumn{3}{|c|}{ RE Tobit } & \multicolumn{3}{|c|}{ FE Negative Binomial Model } \\
\hline Explanat. Var.: & (1) & (2) & (3) & (4) & $(5)$ & (6) & (7) & (8) & (9) \\
\hline Tax Rate Difference & $\begin{array}{c}-2.148^{* * *} \\
(.553)\end{array}$ & $\begin{array}{c}-1.164^{* *} \\
(.564)\end{array}$ & $\begin{array}{l}-3.340^{*} \\
(2.009)\end{array}$ & $\begin{array}{c}-4.821^{* * *} \\
(1.443)\end{array}$ & $\begin{array}{l}-2.594^{*} \\
(1.476)\end{array}$ & $\begin{array}{c}-4.455^{*} \\
(2.458)\end{array}$ & $\begin{array}{c}-.784^{* *} \\
(.337)\end{array}$ & $\begin{array}{c}-1.102^{* * *} \\
(.355)\end{array}$ & $\begin{array}{c}-1.939^{* * *} \\
(.762)\end{array}$ \\
\hline Log \# Researchers & & $\begin{array}{c}.243 \\
(.228)\end{array}$ & $\begin{array}{l}-.370 \\
(.965)\end{array}$ & & $\begin{array}{c}2.588^{* * *} \\
(.853)\end{array}$ & $\begin{array}{c}-.190 \\
(1.290)\end{array}$ & & $\begin{array}{c}.367^{* * *} \\
(.150)\end{array}$ & $\begin{array}{l}-.205 \\
(.469)\end{array}$ \\
\hline Log GDP & & $\begin{array}{c}-1.139^{* * *} \\
(.176)\end{array}$ & $\begin{array}{l}-1.331 \\
(.845)\end{array}$ & & $\begin{array}{c}-3.185^{* * *} \\
(.444)\end{array}$ & $\begin{array}{l}-1.312 \\
(1.048)\end{array}$ & & $\begin{array}{l}.115^{*} \\
(.064)\end{array}$ & $\begin{array}{l}.430^{* * *} \\
(.117)\end{array}$ \\
\hline Log Employees & & & $\begin{array}{c}.198^{* * *} \\
(.081)\end{array}$ & & & $\begin{array}{l}.441^{* * *} \\
(.146)\end{array}$ & & & $\begin{array}{c}.122^{* * *} \\
(.046)\end{array}$ \\
\hline Year Dummies & $\sqrt{ }$ & $\sqrt{ }$ & $\sqrt{ }$ & $\sqrt{ }$ & $\sqrt{ }$ & $\sqrt{ }$ & $\sqrt{ }$ & $\sqrt{ }$ & $\sqrt{ }$ \\
\hline Time Avg. Expl. V. & & & & $\sqrt{ }$ & $\sqrt{ }$ & $\sqrt{ }$ & & & \\
\hline \# Observations & 28,939 & 28,939 & 4,464 & 28,939 & 28,939 & 4,464 & 26,606 & 26,606 & 3,631 \\
\hline \# Firms & 4,177 & 4,177 & 1,482 & 4,177 & 4,177 & 1,482 & 3,695 & 3,695 & 886 \\
\hline
\end{tabular}

Notes:

Heteroscedasticity robust standard errors adjusted for firm clusters in parentheses. ${ }^{*},{ }^{* *},{ }^{* * *}$ indicates significance at the $10 \%, 5 \%, 1 \%$ level. The observational units are multinational subsidiaries per sample year. All regressions include a full set of firm fixed effects. The dependent variable is the number of patents located at a multinational subsidiary. Tax Rate Difference depicts the unweighted average difference in the statutory tax rates between the considered subsidiary and other group members. Log \# Researchers stands for the natural logarithm of the number of scientific researchers in a country, Log GDP is the natural logarithm of the gross domestic product. Log Employees depicts the natural logarithm ( $\log )$ of the firm's number of employees. FE and RE indicate fixed effect and random effect specifications respectively. Time Avg. Expl. V. indicates that time averaged explanatory variables are included in the estimation. 


\begin{tabular}{|c|c|c|c|c|c|c|c|c|c|c|}
\hline \multicolumn{11}{|c|}{$\begin{array}{c}\text { Table 5: Effects of the Effective Tax Rate } \\
\text { Panel 1995-2003 }\end{array}$} \\
\hline Model & \multicolumn{3}{|c|}{ FE OLS } & \multicolumn{3}{|c|}{ RE Tobit } & \multicolumn{4}{|c|}{ FE Negative Binomial Model } \\
\hline Explanat. Var.: & (1) & (2) & (3) & (4) & (5) & (6) & $(7)$ & (8) & (9) & $(10)$ \\
\hline Effective Tax Rate & $\begin{array}{c}-2.445^{* * *} \\
(.467)\end{array}$ & $\begin{array}{c}-1.629^{* * *} \\
(.472)\end{array}$ & $\begin{array}{c}-5.479^{* * *} \\
(2.222)\end{array}$ & $\begin{array}{c}-5.497^{* * *} \\
(1.058)\end{array}$ & $\begin{array}{c}-4.412^{* * *} \\
(1.068)\end{array}$ & $\begin{array}{c}-7.904^{* * *} \\
(3.005)\end{array}$ & $\begin{array}{c}-.658^{* *} \\
(.318)\end{array}$ & $\begin{array}{c}-1.138^{* * *} \\
(.397)\end{array}$ & $\begin{array}{c}-2.594^{* * *} \\
(.753)\end{array}$ & \\
\hline Statutory Tax Rate & & & & & & & & & & $\begin{array}{c}-2.589^{* * *} \\
(.884)\end{array}$ \\
\hline Log \# Researchers & & $\begin{array}{l}.435^{*} \\
(.244)\end{array}$ & $\begin{array}{l}.367 \\
(.939)\end{array}$ & & $\begin{array}{c}3.092^{* * *} \\
(.687)\end{array}$ & $\begin{array}{c}.917 \\
(1.363)\end{array}$ & & $\begin{array}{l}.412^{* *} \\
(.181)\end{array}$ & $\begin{array}{l}-.098 \\
(.456)\end{array}$ & $\begin{array}{l}-.123 \\
(.364)\end{array}$ \\
\hline Log GDP & & $\begin{array}{c}-.930^{* * *} \\
(.166)\end{array}$ & $\begin{array}{l}-.935 \\
(.834)\end{array}$ & & $\begin{array}{c}-1.951^{* * *} \\
(.447)\end{array}$ & $\begin{array}{c}-.763 \\
(1.176)\end{array}$ & & $\begin{array}{c}.180^{* * *} \\
(.056)\end{array}$ & $\begin{array}{c}.561^{* * *} \\
(.135)\end{array}$ & $\begin{array}{c}.558^{* * *} \\
(.116)\end{array}$ \\
\hline \# Observations & 27,074 & 27,074 & 4,150 & 27,074 & 27,074 & 4,150 & 24,931 & 24,931 & 3,366 & 3,366 \\
\hline \# Firms & 3,896 & 3,896 & 1,392 & 3,896 & 3,896 & 1,392 & 3,456 & 3,456 & 828 & 828 \\
\hline
\end{tabular}

Notes:

Heteroscedasticity robust standard errors adjusted for firm clusters in parentheses. ${ }^{*},{ }^{* *},{ }^{* * *}$ indicates significance at the $10 \%, 5 \%, 1 \%$ level. The observational units are multinational subsidiaries per sample year. All regressions include a full set of firm fixed effects. The dependent variable is the number of patents located at a multinational subsidiary. Effective Tax Rate stands for the effective tax on a subsidiaries' royalty income. Statutory Tax Rate and Withholding Tax Rate depict the statutory and withholding tax rate applicable in the subsidiaries' host country. Log \# Researchers stands for the natural logarithm of the number of scientific researchers in a country, $\log G D P$ is the natural logarithm of the gross domestic product. Log Employees depicts the natural logarithm ( $\mathrm{Log}$ ) of the firm's number of employees. FE and RE indicate fixed effect and random effect specifications respectively. Time Avg. Expl. V. indicates that time averaged explanatory variables are included in the estimation. 


\begin{tabular}{|c|c|c|c|c|c|c|c|c|c|}
\hline \multicolumn{10}{|c|}{$\begin{array}{c}\text { Table 6: Effects of CFC Legislations } \\
\text { Panel 1995-2003 }\end{array}$} \\
\hline Model & \multicolumn{3}{|c|}{ FE OLS } & \multicolumn{3}{|c|}{ RE Tobit } & \multicolumn{3}{|c|}{ FE Negative Binomial Model } \\
\hline Explanat. Var.: & (1) & (2) & (3) & (4) & (5) & (6) & (7) & (8) & (9) \\
\hline Statutory Tax Rate & $\begin{array}{c}-1.751^{* * *} \\
(.194)\end{array}$ & $\begin{array}{c}-1.131^{* * *} \\
(.201)\end{array}$ & $\begin{array}{l}-1.950^{*} \\
(1.102)\end{array}$ & $\begin{array}{c}-4.799^{* * *} \\
(.443)\end{array}$ & $\begin{array}{c}-3.134^{* * *} \\
(.574)\end{array}$ & $\begin{array}{c}-4.824^{* * *} \\
(1.369)\end{array}$ & $\begin{array}{c}-.764^{* * *} \\
(.206)\end{array}$ & $\begin{array}{c}-1.021^{* * *} \\
(.168)\end{array}$ & $\begin{array}{c}-1.296^{* * *} \\
(.426)\end{array}$ \\
\hline CFC Legislation & $\begin{array}{l}.038 \\
(.124)\end{array}$ & $\begin{array}{l}.004 \\
(.125)\end{array}$ & $\begin{array}{l}.069 \\
(.377)\end{array}$ & $\begin{array}{l}-.014 \\
(.310)\end{array}$ & $\begin{array}{l}-.126 \\
(.267)\end{array}$ & $\begin{array}{l}-.156 \\
(.653)\end{array}$ & $\begin{array}{c}-.325^{* * *} \\
(.097)\end{array}$ & $\begin{array}{c}-.323^{* * *} \\
(.091)\end{array}$ & $\begin{array}{l}-.319^{*} \\
(.197)\end{array}$ \\
\hline Log \# Researchers & & $\begin{array}{l}.299^{* * *} \\
(.098)\end{array}$ & $\begin{array}{l}-.005 \\
(.445)\end{array}$ & & $\begin{array}{c}1.710^{* * *} \\
(.420)\end{array}$ & $\begin{array}{l}.767 \\
(.824)\end{array}$ & & $\begin{array}{l}.199^{* *} \\
(.096)\end{array}$ & $\begin{array}{l}.194 \\
(.211)\end{array}$ \\
\hline Log GDP & & $\begin{array}{c}-.751^{* * *} \\
(.097)\end{array}$ & $\begin{array}{c}-1.749^{* * *} \\
(.565)\end{array}$ & & $\begin{array}{c}-2.315^{* * *} \\
(.347)\end{array}$ & $\begin{array}{c}-1.668^{* * *} \\
(.624)\end{array}$ & & $\begin{array}{l}.115^{*} \\
(.064)\end{array}$ & $\begin{array}{c}.424^{* * *} \\
(.102)\end{array}$ \\
\hline Log Employees & & & $\begin{array}{c}.192^{* * *} \\
(.048)\end{array}$ & & & $\begin{array}{c}.431^{* * *} \\
(.076)\end{array}$ & & & $\begin{array}{c}.092^{* * *} \\
(.026)\end{array}$ \\
\hline Year Dummies & $\sqrt{ }$ & $\sqrt{ }$ & $\sqrt{ }$ & $\sqrt{ }$ & $\sqrt{ }$ & $\sqrt{ }$ & $\sqrt{ }$ & $\sqrt{ }$ & $\sqrt{ }$ \\
\hline Time Avg. Expl. V. & & & & $\sqrt{ }$ & $\sqrt{ }$ & $\sqrt{ }$ & & & \\
\hline \# Observations & 85,192 & 85,192 & 11,990 & 85,192 & 85,192 & 11,990 & 79,642 & 79,642 & 9,802 \\
\hline \# Firms & 11,809 & 11,809 & 3,877 & 11,809 & 11,809 & 3,877 & 10,721 & 10,721 & 2,308 \\
\hline
\end{tabular}

Notes:

Heteroscedasticity robust standard errors adjusted for firm clusters in parentheses. ${ }^{*},{ }^{* *},{ }^{* * *}$ indicates significance at the $10 \%, 5 \%, 1 \%$ level. The observational units are multinational subsidiaries per sample year. All regressions include a full set of firm fixed effects. The dependent variable is the number of patents located at a multinational subsidiary. Statutory Tax Rate depicts the statutory tax rate applicable in the subsidiaries' host country. CFC Legislation is a dummy variable which takes on the value 1 if the affiliate income is subject to a binding CFC legislation in the parent country. Log \# Researchers stands for the natural logarithm of the number of scientific researchers in a country, $\log G D P$ is the natural logarithm of the gross domestic product. Log Employees depicts the natural logarithm (Log) of the firm's number of employees. FE and RE indicate fixed effect and random effect specifications respectively. Time Avg. Expl. V. indicates that time averaged explanatory variables are included in the estimation. 


\section{CESifo Working Paper Series}

for full list see www.cesifo-group.org/wp

(address: Poschingerstr. 5, 81679 Munich, Germany, office@cesifo.de)

2817 Horst Raff and Nicolas Schmitt, Imports, Pass-Through, and the Structure of Retail Markets, October 2009

2818 Paul De Grauwe and Daniel Gros, A New Two-Pillar Strategy for the ECB, October 2009

2819 Guglielmo Maria Caporale, Thouraya Hadj Amor and Christophe Rault, International Financial Integration and Real Exchange Rate Long-Run Dynamics in Emerging Countries: Some Panel Evidence, October 2009

2820 Saša Žiković and Randall K. Filer, Hybrid Historical Simulation VaR and ES: Performance in Developed and Emerging Markets, October 2009

2821 Panu Poutvaara and Andreas Wagener, The Political Economy of Conscription, October 2009

2822 Steinar Holden and Åsa Rosén, Discrimination and Employment Protection, October 2009

2823 David G. Mayes, Banking Crisis Resolution Policy - Lessons from Recent Experience Which elements are needed for robust and efficient crisis resolution?, October 2009

2824 Christoph A. Schaltegger, Frank Somogyi and Jan-Egbert Sturm, Tax Competition and Income Sorting: Evidence from the Zurich Metropolitan Area, October 2009

2825 Natasa Bilkic, Thomas Gries and Margarethe Pilichowski, Stay in School or Start Working? - The Human Capital Investment Decision under Uncertainty and Irreversibility, October 2009

2826 Hartmut Egger and Udo Kreickemeier, Worker-Specific Effects of Globalisation, October 2009

2827 Alexander Fink and Thomas Stratmann, Institutionalized Bailouts and Fiscal Policy: The Consequences of Soft Budget Constraints, October 2009

2828 Wolfgang Ochel and Anja Rohwer, Reduction of Employment Protection in Europe: A Comparative Fuzzy-Set Analysis, October 2009

2829 Rainald Borck and Martin Wimbersky, Political Economics of Higher Education Finance, October 2009

2830 Torfinn Harding and Frederick van der Ploeg, Is Norway's Bird-in-Hand Stabilization Fund Prudent Enough? Fiscal Reactions to Hydrocarbon Windfalls and Graying Populations, October 2009 
2831 Klaus Wälde, Production Technologies in Stochastic Continuous Time Models, October 2009

2832 Biswa Bhattacharyay, Dennis Dlugosch, Benedikt Kolb, Kajal Lahiri, Irshat Mukhametov and Gernot Nerb, Early Warning System for Economic and Financial Risks in Kazakhstan, October 2009

2833 Jean-Claude Trichet, The ECB's Enhanced Credit Support, October 2009

2834 Hans Gersbach, Campaigns, Political Mobility, and Communication, October 2009

2835 Ansgar Belke, Gunther Schnabl and Holger Zemanek, Real Convergence, Capital Flows, and Competitiveness in Central and Eastern Europe, October 2009

2836 Bruno S. Frey, Simon Luechinger and Alois Stutzer, The Life Satisfaction Approach to Environmental Valuation, October 2009

2837 Christoph Böhringer and Knut Einar Rosendahl, Green Serves the Dirtiest: On the Interaction between Black and Green Quotas, October 2009

2838 Katarina Keller, Panu Poutvaara and Andreas Wagener, Does Military Draft Discourage Enrollment in Higher Education? Evidence from OECD Countries, October 2009

2839 Giovanni Cespa and Xavier Vives, Dynamic Trading and Asset Prices: Keynes vs. Hayek, October 2009

2840 Jan Boone and Jan C. van Ours, Why is there a Spike in the Job Finding Rate at Benefit Exhaustion?, October 2009

2841 Andreas Knabe, Steffen Rätzel and Stephan L. Thomsen, Right-Wing Extremism and the Well-Being of Immigrants, October 2009

2842 Andrea Weber and Christine Zulehner, Competition and Gender Prejudice: Are Discriminatory Employers Doomed to Fail?, November 2009

2843 Hadi Salehi Esfahani, Kamiar Mohaddes and M. Hashem Pesaran, Oil Exports and the Iranian Economy, November 2009

2844 Ruediger Bachmann and Christian Bayer, Firm-Specific Productivity Risk over the Business Cycle: Facts and Aggregate Implications, November 2009

2845 Guglielmo Maria Caporale, Burcu Erdogan and Vladimir Kuzin, Testing for Convergence in Stock Markets: A Non-Linear Factor Approach, November 2009

2846 Michèle Belot and Jan Fidrmuc, Anthropometry of Love - Height and Gender Asymmetries in Interethnic Marriages, November 2009

2847 Volker Nitsch and Nikolaus Wolf, Tear Down this Wall: On the Persistence of Borders in Trade, November 2009 
2848 Jan K. Brueckner and Stef Proost, Carve-Outs Under Airline Antitrust Immunity, November 2009

2849 Margarita Katsimi and Vassilis Sarantides, The Impact of Fiscal Policy on Profits, November 2009

2850 Scott Alan Carson, The Relationship between Stature and Insolation: Evidence from Soldiers and Prisoners, November 2009

2851 Horst Raff and Joachim Wagner, Intra-Industry Adjustment to Import Competition: Theory and Application to the German Clothing Industry, November 2009

2852 Erkki Koskela, Impacts of Labor Taxation with Perfectly and Imperfectly Competitive Labor Markets under Flexible Outsourcing, November 2009

2853 Cletus C. Coughlin and Dennis Novy, Is the International Border Effect Larger than the Domestic Border Effect? Evidence from U.S. Trade, November 2009

2854 Johannes Becker and Clemens Fuest, Source versus Residence Based Taxation with International Mergers and Acquisitions, November 2009

2855 Andreas Hoffmann and Gunther Schnabl, A Vicious Cycle of Manias, Crashes and Asymmetric Policy Responses - An Overinvestment View, November 2009

2856 Xavier Vives, Strategic Supply Function Competition with Private Information, November 2009

2857 M. Hashem Pesaran and Paolo Zaffaroni, Optimality and Diversifiability of Mean Variance and Arbitrage Pricing Portfolios, November 2009

2858 Davide Sala, Philipp J.H. Schröder and Erdal Yalcin, Market Access through Bound Tariffs, November 2009

2859 Ben J. Heijdra and Pim Heijnen, Environmental Policy and the Macroeconomy under Shallow-Lake Dynamics, November 2009

2860 Enrico Spolaore, National Borders, Conflict and Peace, November 2009

2861 Nina Czernich, Oliver Falck, Tobias Kretschmer and Ludger Woessmann, Broadband Infrastructure and Economic Growth, December 2009

2862 Evžen Kočenda and Martin Vojtek, Default Predictors and Credit Scoring Models for Retail Banking, December 2009

2863 Christian Gollier and Martin L. Weitzman, How Should the Distant Future be Discounted when Discount Rates are Uncertain?, December 2009

2864 Tiberiu Dragu and Mattias Polborn, Terrorism Prevention and Electoral Accountability, December 2009 
2865 Torfinn Harding and Beata Smarzynska Javorcik, A Touch of Sophistication: FDI and Unit Values of Exports, December 2009

2866 Matthias Dischinger and Nadine Riedel, There's no Place like Home: The Profitability Gap between Headquarters and their Foreign Subsidiaries, December 2009

2867 Andreas Haufler and Frank Stähler, Tax Competition in a Simple Model with Heterogeneous Firms: How Larger Markets Reduce Profit Taxes, December 2009

2868 Steinar Holden, Do Choices Affect Preferences? Some Doubts and New Evidence, December 2009

2869 Alberto Asquer, On the many Ways Europeanization Matters: The Implementation of the Water Reform in Italy (1994-2006), December 2009

2870 Choudhry Tanveer Shehzad and Jakob De Haan, Financial Reform and Banking Crises, December 2009

2871 Annette Alstadsæter and Hans Henrik Sievertsen, The Consumption Value of Higher Education, December 2009

2872 Chris van Klaveren, Bernard van Praag and Henriette Maassen van den Brink, Collective Labor Supply of Native Dutch and Immigrant Households in the Netherlands, December 2009

2873 Burkhard Heer and Alfred Maußner, Computation of Business-Cycle Models with the Generalized Schur Method, December 2009

2874 Carlo Carraro, Enrica De Cian and Massimo Tavoni, Human Capital Formation and Global Warming Mitigation: Evidence from an Integrated Assessment Model, December 2009

2875 André Grimaud, Gilles Lafforgue and Bertrand Magné, Climate Change Mitigation Options and Directed Technical Change: A Decentralized Equilibrium Analysis, December 2009

2876 Angel de la Fuente, A Mixed Splicing Procedure for Economic Time Series, December 2009

2877 Martin Schlotter, Guido Schwerdt and Ludger Woessmann, Econometric Methods for Causal Evaluation of Education Policies and Practices: A Non-Technical Guide, December 2009

2878 Mathias Dolls, Clemens Fuest and Andreas Peichl, Automatic Stabilizers and Economic Crisis: US vs. Europe, December 2009

2879 Tom Karkinsky and Nadine Riedel, Corporate Taxation and the Choice of Patent Location within Multinational Firms, December 2009 